Research paper

\title{
Suitability of the Weber-Gut risk assessment methodology used in Central Europe for determining invasive woody plant species in Estonian historical parks
}

\author{
Nele Nutt* and Ardo Kubjas
}

Nutt, N., Kubjas, A. 2020. Suitability of the Weber-Gut risk assessment methodology used in Central Europe for determining invasive woody plant species in Estonian historical parks. Forestry Studies | Metsanduslikud Uurimused 72, 21-33, ISSN 1406-9954. Journal homepage: http:/ / mi.emu.ee/forestry.studies

\begin{abstract}
The main objective of this research was to assess the suitability of the risk assessment methodology developed by Weber \& Gut for Central Europe in order to determine the invasive species in the dendroflora of this region's historical parks. In order to do so a region was chosen where the number of old parks is high (Estonia) and then the following characteristics were studied: 1) the distribution of invasive species; 2) the viability of invasive species. Research results showed that the risk assessment for Central Europe developed by Weber \& Gut is not suitable for determining invasive tree and shrub species in the historical parks of Estonia. The research viewed 18 species (classified as a high-risk category) and only half of them had characteristics inherent to invasive behaviour (produces reproductive offspring, often in very large numbers, at a considerable distance from parent plants, and thus has the potential to spread over a considerable area). Even in a small territory $\left(45,339 \mathrm{~km}^{2}\right)$, the regional differences in the occurrence of invasive species were substantial. No independent mass reproduction of most of the invasive species was detected during the use of the WeberGut risk assessment system. This research showed that the dangers of invasive species cannot be assessed based on one methodology, but each species should be assessed according to their habitat and specifics of the species.
\end{abstract}

Key words: dendroflora, alien species, exotic species, biological invasion, environmental weed.

Authors' addresses: Tartu College, School of Engineering, Tallinn University of Technology and Academy of Architecture and Urban Studies, Department of Civil Engineering and Architecture, School of Engineering, Tallinn University of Technology, Ehitajate tee 5, 19086 Tallinn, Estonia; *e-mail: nele.nutt@taltech.ee

\section{Introduction}

\section{The problem of invasive species}

Invasive alien species are the second largest reason after habitat destruction for the decrease in biodiversity all over the world (European Commission, 2013). The Euro- pean Union has taken several measures to preserve biodiversity by limiting the spread of invasive alien species. Compared to herbaceous plants the problem of invasive slow-growing and long-living woody plants has not received much attention. Invasion of non-native species is one of the 
many threats to biodiversity and it is considered to be a major component of global change (Mooney \& Hobbs, 2000). The problem of invasive species increases constantly due to the increase in people travelling and goods being transported. Although for a long time, exotic species have been valuable and desirable souvenirs brought home from travels to distant countries but they have also become a problem which is being dealt with at a national level. The shorter the lifespan of a species, the faster it reproduces, hence the greater risk of invasion by alien species. Therefore, the invasion of herbaceous plants is a rapidly growing issue. There seems to be no serious danger when talking about species with a long lifespan, such as woody plants. Alien woody plants have not been considered to be dangerous invasive species (Holm et al., 1997) but the problem has become significant in many regions due to greater distribution and naturalisation of woody plants. Seven woody plants (DAISIE, 2017) are listed amongst one hundred most dangerous invasive species in Europe.

\section{Invasive woody plants in Estonian parks based on the Weber-Gut risk assessment system}

Invasive herbaceous plants have been studied more than woody plants (Ööpik et al., 2008; Sander et al., 2008; Raska, 2010; Purik, 2011; Ööpik et al., 2013), but research about woody plants (Elliku \& Sander, 1996; Mölter, 2011), manor parks (Uustal, 2003; Nutt, 2008; Sinijärv, 2013; Nurme et al., 2014) and the dendroflora of manor parks (Nutt, 2013; Nutt et al., 2013) have also been carried out. However, the species invading the parks' dendroflora have not been studied. A Master's thesis titled Risk assessment of alien woody plant species recommended for restoration of parks was defended in 2013 at the Estonian University of Life Sciences (Purik, 2013). The thesis drew attention to parks as a hotbed of invasive tree and shrub species reproduction which was considered to be a problem in the restoration of parks. Fifty-three species of alien woody plants in parks were classified into three categories (Purik, 2013) according to their invasion potential in 2013 and on the basis of the Weber-Gut risk assessment system which was previously used in Central Europe (Weber \& Gut, 2004). In Estonia, 18 woody plants (Purik \& Ööpik, 2013) have been listed as invasive amongst other alien species. In order to evaluate the extent of the problem of invasive species that belong to the high-risk category, the distribution of alien invasive tree species in Estonian parks classified as high risk was analysed in 2013 (Purik, 2013).

\section{Material and Methods}

\section{Estonian Historical Parks}

Estonia with a total area of $45,339 \mathrm{~km}^{2}$ has about 1,100 manors (Rosenberg, 1994) and about 800 parks which have been preserved. The oldest manor parks were established already in the $17^{\text {th }}$ century (Maiste, 1996) and a majority of the parks were founded in the $18^{\text {th }}-19^{\text {th }}$ century (Nutt et al., 2013).

The use of alien plant species in park design began in the middle of the $19^{\text {th }}$ century (Sinijärv, 2013). It is known that alien species can be bought from plant nurseries but also brought from trips abroad (Nutt, 2008). Although historical events have had a devastating effect on parks that once were magnificent and many exotic species susceptible to local climate have been destroyed, there are still resistant species which can reproduce without special care. The issue of invasive woody plants in Estonian parks was recognised in regard to the restoration of old manor parks (Purik \& Ööpik, 2013).

\section{Description of the area - climate, soil and dendroflora}

The distribution, viability and invasiveness of species are largely dependent on natural conditions (Pyšek et al., 2008). Esto- 
nia is located in Northern Europe (580-600 N, 220-280 E). The territory of Estonia covers $45,339 \mathrm{~km}^{2}$ and lies on the eastern coast of the Baltic Sea (the coastline is $3,794 \mathrm{~km}$ long). The average height is $50 \mathrm{~m}$ above sea level $(\max 317.4 \mathrm{~m})$. Estonia is located in the transitional temperate climate zone and the climate is strongly influenced by the North Atlantic Current, the Baltic Sea and the geographical location of Estonia. Estonia has four seasons and the annual average temperature is about $+5{ }^{\circ} \mathrm{C}$ (average temperature in February is $-4 \ldots-5^{\circ} \mathrm{C}$ and $+18^{\circ} \mathrm{C}$ in July). Temperature fluctuations from the average are frequent. Precipitation surpasses the evaporation rate. The annual precipitation rate is between 550$800 \mathrm{~mm}$, on average, and the average relative humidity is $80-83 \%$. In Estonia, the vegetation period is almost 200 days, on average (between 175-195 days), being the shortest in the north-eastern part (less than 180 days) and longest in South Estonia and islands (more than 185 days). (Estonica, 2020).

The characteristic features of soil in Estonia are as follows (Raukas, 1995): 1) abundance of wetland soils; 2) presence of limestone in the soils; 3) abundance of carbonate soils; 4) soils are rich in stones, especially gravel; 5) the soils are colourful due to their granulometric, mineral and chemical composition, and variable water regime. About half of the territory (45.6\%) of Estonia is covered with forests (Adermann, 2009) and there are 81 indigenous woody plant species (Kull, 2009).

\section{Database and analysis}

The materials used for the analysis included lists of tree and shrub species growing in parks (compiled between 1970 and the 1990s) and data on dendrological inventories (from 2003 to 2009), which enabled to analyse which species form so-called new natural communities. The occurrence of all invasive woody plants was analysed by regions. The analysis included coniferous and deciduous trees and shrubs classified as high-risk species by Purik \& Ööpik (2013): three coniferous species ( $A b$ ies balsamea (L.) Mill., Abies sibirica Ledeb., Larix decidua Mill.) and 15 deciduous species (Acer negundo L., Acer pseudoplatanus L., Acer saccharium L., Amelanchier spicata (Lam.) K. Koch, Cornus alba L., Populus alba L., Populus balsamifera L., Robinia pseudoacacia L., Rosa pimpinellifolia L., Rubus odoratus L., and shrub species Caragana arborescens Lam., Sambucus racemose L., Sorbaria sorbifolia (L.) A. Braun, Symphoricarpos albus (L.) S. F. Blake, Physocarpus opulifolius (L.) Maxim.).

Several databases were used to assess the distribution of invasive tree species in parks as follows:

1. The analysis of the distribution of invasive species is based on Piret Palm's database which was compiled in 2009 (Palm, 2009). Data was collected from inventories which were prepared during the period of 1977 to 1997 . The database contains 370 tree and shrub species in 304 parks all over Estonia (Figure 1). Data analysis was performed using the statistical programming language R. A distribution map was compiled about each species which helped to view the dangers of invasion region (county) by region. Comparing the distribution maps to each other enabled to assess the peculiarities and extent of the dangers of invasion. In order to characterise the frequency of distribution in each region, a percentage of the species' occurrence was calculated in all of these parks, county by county.

2. The viability of invasive species was analysed from 2003 to 2009 on the basis of the dendrological inventory data of 17 parks (Table 1). The data used in the analysis included 13,994 trees. Their species and breast height diameter were determined and their age was calculated based on the breast height diameter methodology (Nutt et al., 2013) which considers the growth speed of a tree species (either coniferous, deciduous 
hard or soft tree). All the trees were divided into two age groups: old (more than 100 years old) and young (less than 100 years old) (Nutt et al., 2013). Based on the difference in the number of old and young individuals the species' viability or ability to reproduce was determined. The database included 1,836 coniferous and 12,108 deciduous trees. There were 11,902 native trees and 2,042 exotic trees. Deciduous trees prevailed among native species (11,218 trees), outnumbering coniferous trees (684). There were 1,152 coniferous and 890 deciduous trees among exotic species. Altogether, there were 571 invasive species among exotic species, 549 of which were coniferous and 22 deciduous. In order to evaluate the extent of the problem of high-risk invasive species the distribution of alien invasive tree species classified as high risk in Estonian parks was analysed in 2013 (Purik, 2013). Freeware R was used for data analysis.

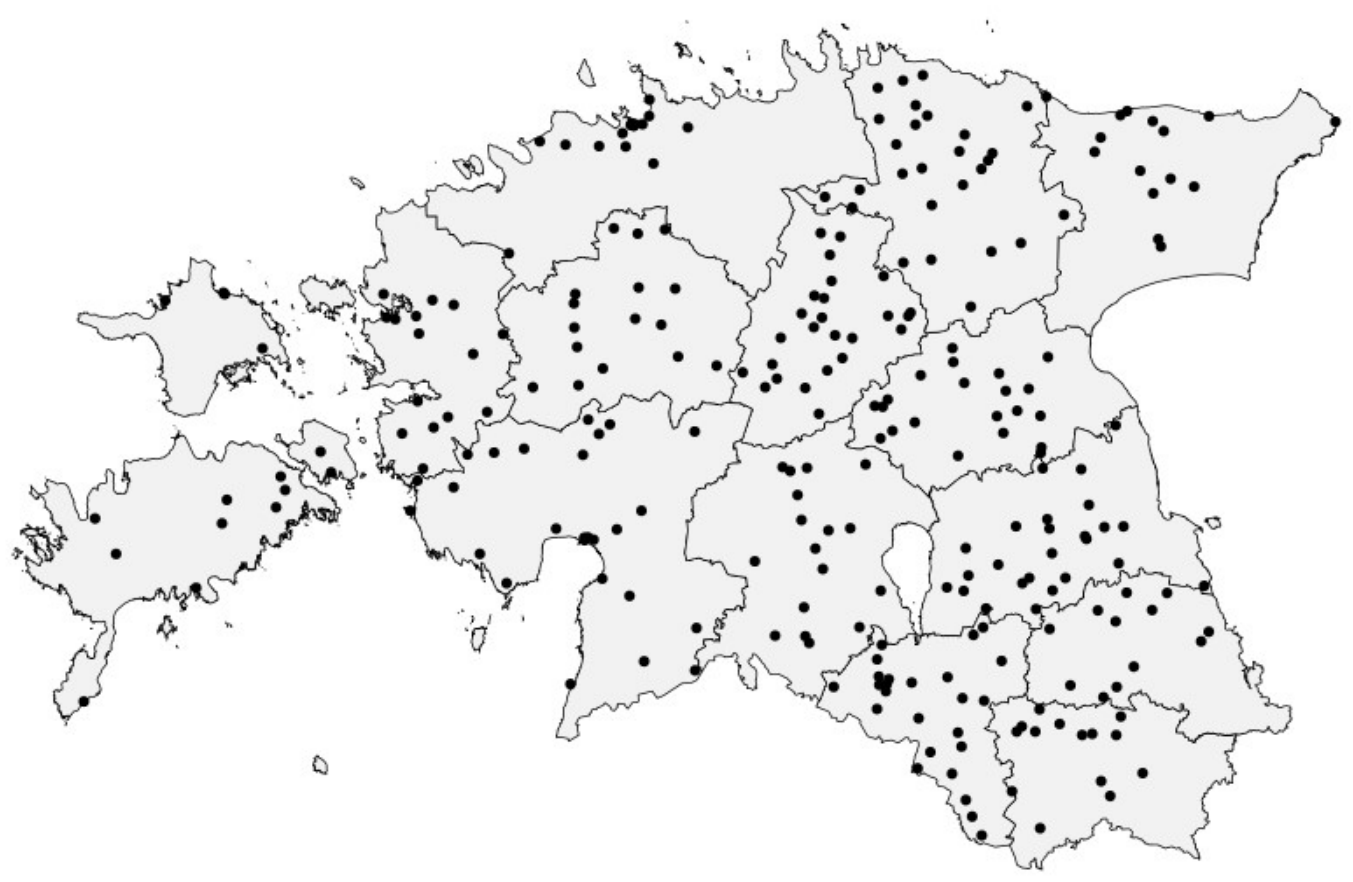

Figure 1. The location of parks in counties included in the research. 
Table 1. Overview of inventories used in the research. The inventories are compiled by Artes Terrae Ltd.

\begin{tabular}{|c|c|c|}
\hline Name of the park & Year of the inventory & Name of the project \\
\hline Hummuli manor park & 2008 & Reconstruction project of Hummuli manor park \\
\hline Härgla manor park & 2007 & Dendrological inventory of Härgla manor park \\
\hline Kiidjärve manor park & 2009 & Reconstruction project of Kiidjärve manor park \\
\hline Kukruse manor park & 2009 & Reconstruction project of Kukruse manor park \\
\hline Kuremaa manor park & 2006 & Reconstruction project of Kuremaa manor park \\
\hline Lõhavere Hospital park & 2009 & Dendrological inventory of Lõhavere Hospital park \\
\hline Mäetaguse manor park & 2004 & Reconstruction project of Mäetaguse manor park \\
\hline Pagari manor park & 2007 & Reconstruction project of Pagari manor park \\
\hline Puurmani manor park & 2007 & Reconstruction project of Puurmani manor park \\
\hline Püssi manor park & 2007 & Reconstruction project of Püssi manor park \\
\hline Riidaja manor park, I phase & 2006 & Reconstruction project of Riidaja manor park, I phase \\
\hline Rõngu castle hill park & 2008 & $\begin{array}{l}\text { Dendrological assessment of Rõngu castle hill park and } \\
\text { recommendations for management }\end{array}$ \\
\hline Saka manor park & 2008 & Reconstruction project of Saka manor park \\
\hline Saku manor park & 2007 & Reconstruction project of Saku manor park \\
\hline Sürgavere manor park & 2008 & Reconstruction project of Sürgavere manor park \\
\hline Õisu manor park & 2008 & Reconstruction project of Õisu manor park \\
\hline Rogosi manor park & 2003 & $\begin{array}{l}\text { Dendrological inventory and assessment of Rogosi } \\
\text { manor park }\end{array}$ \\
\hline
\end{tabular}

\section{Results}

\section{Analysis of the distribution of invasive species}

Three species of coniferous trees categorised as high risk are abundant in parks. The most numerous invasive coniferous species is European larch (Larix decidua) which grows in $64 \%$ of the parks. Two fir species are a little less abundant (Abies sibirica 55\% and Abies balsamea 38\%).
Although European larch (Larix decidua) was the most numerous coniferous tree in parks (in $64 \%$ of the parks) (Table 2), there were remarkable differences in its regional distribution. In West Estonia and the western islands, the occurrence of the species was less frequent. In addition, there was not a single Abies sibirica in the parks of the southwestern region, including the islands (Figure 2). The same pattern occurred with other coniferous species (Abies balsamea, Larix decidua). 
Table 2. The occurrence of high-risk invasive tree and shrub species in parks by species (data of 304 parks).

\begin{tabular}{llcc}
\hline No & Species name & $\begin{array}{c}\text { No of } \\
\text { parks }\end{array}$ & $\begin{array}{c}\% \text { of } \\
\text { parks }\end{array}$ \\
\hline 1 & Caragana arborescens & 244 & 80 \\
2 & Larix decidua & 194 & 64 \\
3 & Sambucus racemosa & 192 & 63 \\
4 & Sorbaria sorbifolia & 171 & 56 \\
5 & Abies sibirica & 168 & 55 \\
6 & Symphoricarpos albus & 167 & 55 \\
7 & Abies balsamea & 117 & 38 \\
8 & Cornus alba & 115 & 38 \\
9 & Physocarpus opulifolius & 84 & 28 \\
10 & Populus alba & 75 & 25 \\
11 & Acer negundo & 71 & 23 \\
12 & Rosa pimpinellifolia & 70 & 23 \\
13 & Amelanchier spicata & 58 & 19 \\
14 & Acer pseudoplatanus & 56 & 18 \\
15 & Populus balsamifera & 42 & 14 \\
16 & Acer saccharinum & 18 & 6 \\
17 & Robinia pseudoacacia & 17 & 6 \\
18 & Rubus odoratus & 15 & 5 \\
\hline
\end{tabular}

Compared to coniferous trees, there were fewer invasive deciduous trees or shrubs in parks (Table 2, Figure 1). The northern region was exceptional because Acer pseudoplatanus was found in over $70 \%$ of the parks. Populus alba was present in $80 \%$ of the parks on the islands and Amelanchier spicata in $60 \%$ of the parks in the southern region. There were only a few samples of Acer saccharinum and Robinia pseudoacacia found in all the parks (Figure 3).

The most widely distributed species are mostly shrub species. Caragana arborescens, which belongs to the third risk category, is widespread (found in $80 \%$ of the researched parks) (Figure 4). Sambucus racemosa (63\%), Sorbaria sorbifolia (56\%),
Symphoricarpos albus (55\%) appear in about half of the studied parks. The most abundant invasive shrub species is Caragana arborescens which occurs in $90 \%$ of the parks in different regions. Symphocarpos albus and Sambucus racemosa are also present in over $40 \%$ of the parks, and Sorbaria sorbifolia is in $20 \%$ of the parks in the western region. Rubus odoratus is not present in the western region and on islands and in other regions can be found in less than $15 \%$ of the parks. The smallest number of invasive species is in the western part of Estonia where half of the invasive species are present, and on the islands where only 11 species can be found.

The difference in the presence of coniferous trees in the western region compared to the rest of Estonia is noticeable - two species cannot be found in any of the parks in the western region and only one species occurs in the parks of the islands. The deciduous species Acer pseudoplatanus occurred in the northern region (in 70\% of the parks), Populus alba on southwestern islands (in $80 \%$ of the parks) and in the southern region. Amelanchier spicata was present in $60 \%$ of the parks. Robinia pseudoacacia and Acer saccharinum were present only in small numbers (0-20\%). Distribution of the shrub species Caragana arborescens was very high. Also, Symphocarpos albus, Sambucus racemosa, Sorbaria sorbifolia were abundant. However, the distribution of Rubus odoratus and Cornus alba was very small.

\section{Analysis of the viability of invasive species}

In order to analyse the severity of the problem of invasion, the parks that had the highest number of species' individuals and invasive offspring present were analysed.

The proportion of young trees growing in parks that have reproduced naturally is very small, which means that many species do not reproduce independently and thus fail to pose an invasive threat (Figure 5). The number of invasive coniferous and deciduous trees in sixteen different parks was generally under 40 . 


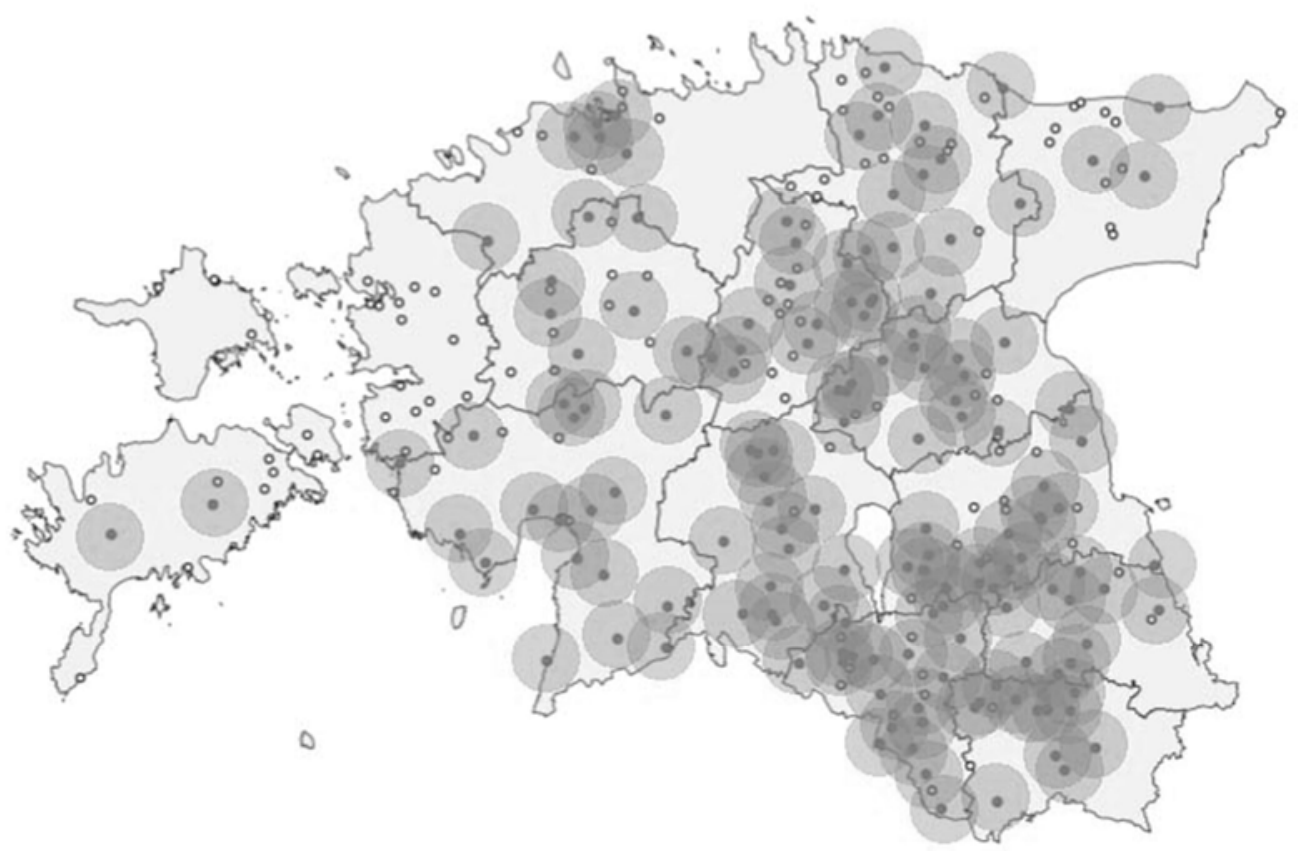

Figure 2. The distribution of an invasive species Abies sibirica (data of 304 parks). There was not a single Abies sibiricain the parks of the southwestern region. Circles mark the places where the species were found (in parks). The closer the circles are to each other, the more there are parks where the species were identified.

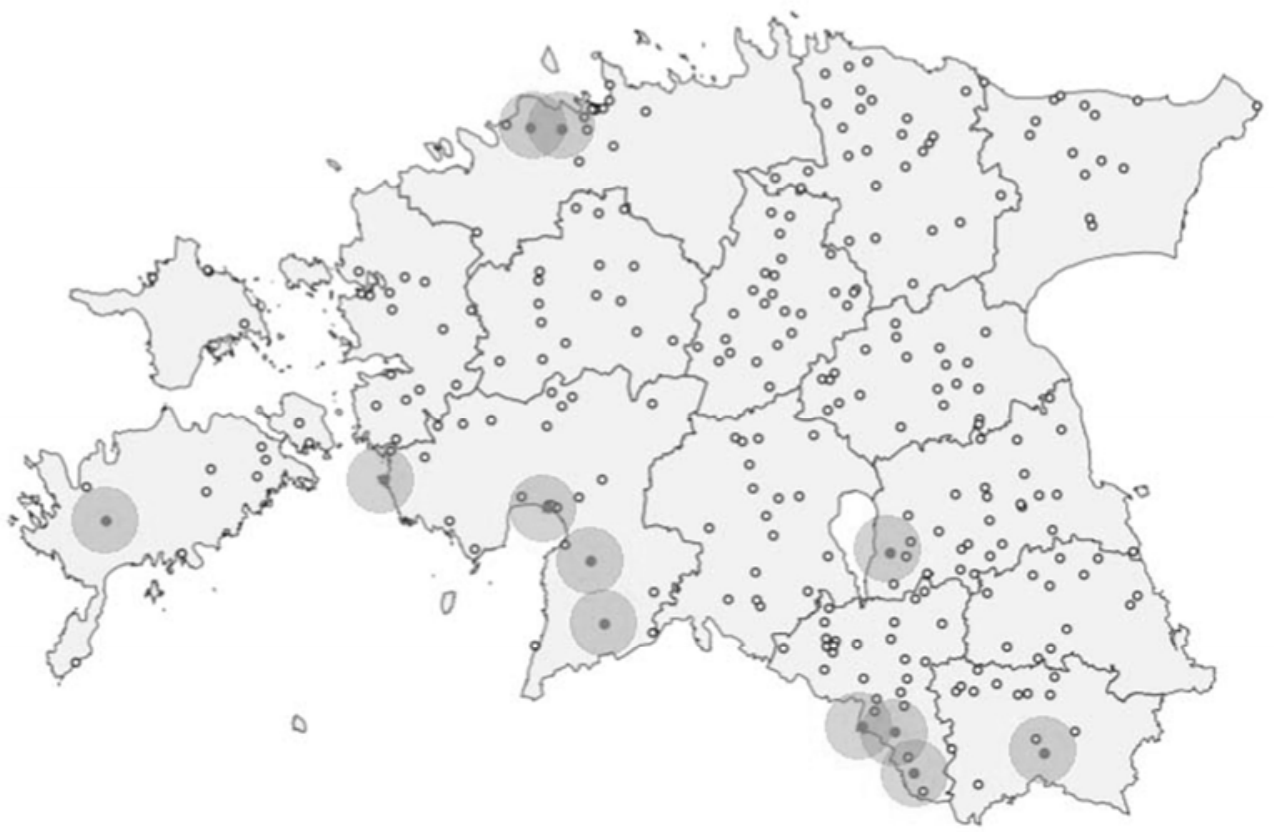

Figure 3. The distribution of an invasive species Robinia pseudoacacia. Only a few samples of Robinia pseudoacacia were found (data of 304 parks). 


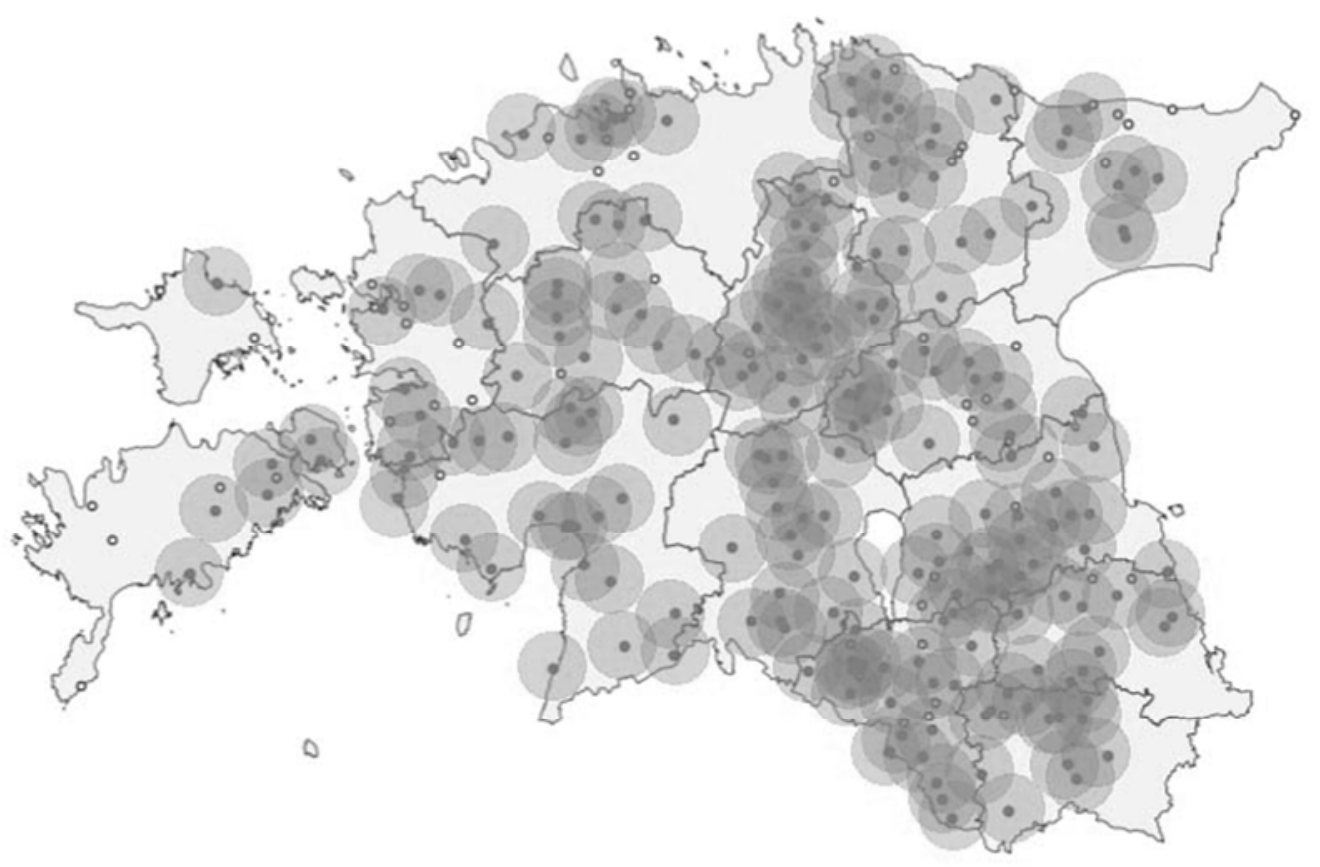

Figure 4. The distribution of an invasive shrub Caragana arborescens found in $80 \%$ of the parks (data of 304 parks).

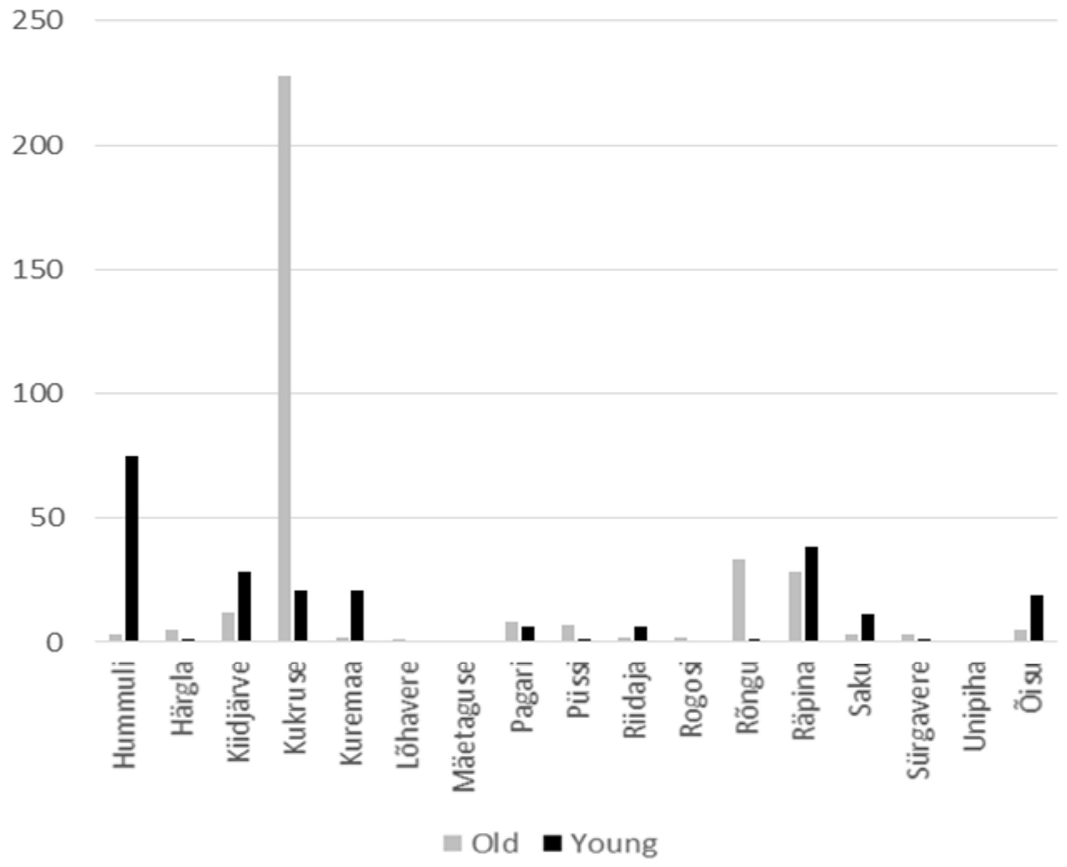

Figure 5. Number of invasive trees in parks, coniferous and deciduous. Old and young invasive trees in parks (data of 17 parks). 
The number of invasive trees is bigger in Hummuli and Räpina manor park, and in Kukruse manor park which is an exception as there is a European larch (Larix decidua) alley with 250 trees.

The three coniferous trees categorised as invasive (Larix decidua, Abies sibirica,
Abies balsamea) produced offspring, hence, had new individuals in these parks which shows that the species are able to reproduce. The same conclusion cannot be made about deciduous trees categorised as invasive because only one species had new individuals in one park (Table 3).

Table 3. The distribution and viability of invasive species (data of 304 parks).

\begin{tabular}{llcl}
\hline No & Species name & No of parks present & Remarks (viability) \\
\hline 1 & Caragana arborescens & 8 & shrub \\
2 & Larix decidua & 10 & $\begin{array}{l}\text { was not present, except in Kukruse is present in } \\
\text { large numbers }\end{array}$ \\
3 & Sambucus racemosa & 2 & shrub \\
4 & Sorbaria sorbifolia & 1 & shrub \\
5 & Abies sibirica & 8 & present in large numbers \\
6 & Symphoricarpos albus & 6 & shrub \\
7 & Abies balsamea & 8 & present in large numbers \\
8 & Cornus alba & 3 & shrub \\
9 & Physocarpus opulifolius & 0 & - \\
10 & Populus alba & 2 & was not present \\
11 & Acer negundo & 3 & was not present \\
12 & Rosa pimpinellifolia & 0 & - \\
13 & Amelanchier spicata & 0 & - \\
14 & Acer pseudoplatanus & 4 & a few individuals \\
15 & Populus balsamifera & 0 & - \\
16 & Acer saccharinum & 2 & was not present \\
17 & Robinia pseudoacacia & 0 & was not present \\
18 & Rubus odoratus & & - \\
\hline
\end{tabular}

\section{Discussion}

This article gives an overview of the invasion problem of slow-growing and long-living woody plant species in the parks of Estonia. When using the Weber-Gut risk assessment system used in Central Europe, the number of alien woody plant species was 53 in 2013, which were divided into three risk categories (Purik \& Ööpik,
2013). In order to evaluate the severity of the invasion problem, the plants' species and age were analysed which enabled to determine their distribution and viability or reproduction ability.

The study showed that based on the Weber-Gut risk assessment system used in Central Europe all the species categorised as high risk (total of 18) had not reproduced or produced an offspring in these 
parks. Therefore, adding them to the list and classifying them as high risk is not justified in Estonia. The species Robinia pseudoacacia, Rubus odoratus, Acer saccharinum, Populus balsamifera, Populus alba, Acer negundo, Acer pseudoplatanus were the only deciduous trees that had new individuals. All the coniferous trees on the third risk category list (Larix decidua, Abies sibirica, Abies balsamea) produced offspring.

Although invasive species may cause big problems on a wide scale, this cannot be observed within the tree and shrub species of old manor parks in Estonia, because most exotic species growing there do not compete with native species. There are species that are called invasive but their offspring do not exceed the new individuals of native species and therefore, they do not dominate the native species.

Bioinvasion goes with other processes triggered by man, such as global changes in the environment and climate, and this is considered to be an equal danger to biota next to over-exploitation, change and fragmentation of habitats and pollution (Kangur et al., 2005). This is a complicated issue that needs more complex research in order to study the impact of local environmental conditions (climate, soil, etc.) on invasive species. Foreign species have been intentionally introduced into the parks when they were built $\left(18^{\text {th }}-19^{\text {th }}\right.$ century) and therefore, the distribution of species depended on the owner's personal preferences and if they were able to get the foreign species. The first scientific descriptions of Baltic governorates (Pistohlkors, 1797; Friebe, 1805) highlight the non-local tree species and this marks the beginning of the introduction of foreign species into Baltic governorates (Sander \& Meikar, 2004).

However, there are still some introduced species (Larix decidua, Abies sibirica) which have been adopted in Estonia and used, for example, in forestry (Keskkonnaminister, 2006). It would be incorrect to claim that avoiding the use of the mentioned species would solve the problem.
The issue of invasive species has to be solved in a complex manner, not based on single parks.

The methodology used to determine the viability of trees cannot be applied to shrubs and therefore, a methodology that considers the specific characteristics of shrub reproduction should be used. The distribution of shrubs in parks has to be evaluated. The database that was available did not include the necessary data. A high percentage of young trees in the parks indicates that they are able to reproduce independently. Due to the fact that there is no diameter data on shrubs, it is not possible to assess the natural renewal of shrubs according to their age and hence, assessment of their reproductive abilities should be based on the shrub population and distribution data.

The severity of invasion cannot be evaluated based on the total number of trees. Although the tree species are categorised as high risk, their viability and offspring have to be analysed. Therefore, a comparison of old and young trees was carried out, which showed that in Kukruse park, there are many invasive tree species, although the number of new individuals is small. However, there are still parks (Hummuli, Kiidjärve, Kuremaa, Räpina, Riidaja, and Saku) where the number of new individuals exceeds the number of old trees (Figure 5), which represents a species' ability to reproduce naturally.

From the point of view of the aim of this study, it is clear that the problem of invasiveness cannot be addressed the same way everywhere. It has clear regional peculiarities (Figure 2, 3,4) and the species categorised as high risk are not distributed similarly in all the parks of the studied regions. Also, all the species do not produce new individuals. Corrections have to be made in the invasive species list: 4 tree species (Larix decidua, Abies sibirica, Abies balsamea, Acer pseudoplatanus) and 4 shrub species (Caragana arborescens, Symphocarpos albus, Sambucus racemosa, Sorbaria sorbifolia, 
Physocarpus opulifolius) need to be classified as high-risk category species.

Undoubtedly, current results are not final as the growth and distribution of woody plants is a long-term process. The first alien woody plants were brought to Estonia in the $17^{\text {th }}$ century and from then on the number of introduced species has been growing. The results of this research confirmed the assumption that there are regional variations in the distribution of species. The mild climate of northern Estonia might be the reason why these species can be found in large numbers in this area compared to the inland. But without further research this is not certain because the reason may be historical, i.e. the mentioned species have never been introduced into these parks.

Another aspect is connected with the maintenance of parks. However, in the case of invasive species it may be suggested that maintenance does not play an important role because they should be strong competitors for native species. Still, we estimated that the presence of the so-called invasive species should be viewed in connection with the maintenance of parks.

\section{Conclusion}

- Our research showed that the risk assessment for Central Europe developed by Weber \& Gut is not suitable for determining the invasiveness of tree and shrub species in the historical parks of Estonia.

- Only half of the 18 species (determined to fall in the high-risk category) have characteristics of invasive behaviour (producing reproductive offspring, often in very large numbers, at a considerable distance from parent plants, and thus having the potential to spread over a considerably wide area).

- $\quad$ Even in the relatively small territory of Estonia covered in our research $(45,339$ $\mathrm{km}^{2}$ ), regional differences in the occur- rence of invasive species are noticeable.

- Based on the Weber-Gut risk assessment system we did not recognise mass-independent reproduction of most of the tree species determined as invasive.

- Our research showed that the dangers of invasion cannot be assessed with a single uniform methodology, because each habitat and species needs to be analysed individually and according to their specifics.

Acknowledgements. The authors are thankful to Prof. Zenia Kotval and Prof. Mari Ivask for their help and inspiration, and Mr Sulev Nurme and Artes Terrae OÜ team for their help in fieldwork and collection of dendrological inventory data. The authors would like to thank Karin Muoni and Kadri Mets for improving the English language of the manuscript.

\section{References}

Adermann, V. 2009. Estonian Forests 2008. (Eesti Metsad 2008). Tallinn, Centre of Forest Protection and Silviculture. 134 pp. (In Estonian).

DAISIE. 2017. Delivering Alien Invasive Species Inventories for Europe. [WWW document]. - URL https://www.europe-aliens.org/ aboutDAISIE.do. [Accessed 01 April 2017].

Elliku, J., Sander, H. 1996. Trees and shrubs of Paldiski 2. (Paldiski puud ja põõsad 2). Newspaper Lääne-Harju Ekspress, December 14, November 30 (14. Detsember, 30. November), 11.

Estonica. 2020. Climate. Estonica: Encyclopedia about Estonia. [WWW document] - URL http://www.estonica.org/en/Nature/ Location_and_natural_conditions/Climate/. [Accessed 01 July 2020].

European Commission. 2013. Environment: New EU Action to protect biodiversity against problematic invasive species. [WWW document]. - URL https://ec.europa.eu/commission/presscorner/ detail/en/IP_13_818. [Accessed 03 January 2020].

Friebe, W.Cr. 1805. Economic-Technical Flora for Livonia, Estonia, and Courland. (Oekonomisch-technische Flora für Liefland, Ehstland und Kurland). Riga, Hartmannschen Buchhandlung. 392 pp. 
Holm, L., Doll, J., Holm, E., Pancho, J.V., Herberger, J.P. 1997. World Weeds: Natural Histories and Distribution. New York, John Wiley \& Sons. 1152 pp.

Kangur, M., Kotta, J., Kukk, T., Kull, T., Lilleleht, V., Luig, J., Ojaveer, H., Paalme, T., Vetemaa, M. 2005. Invasive Alien Species in Estonia. (Invasiivsed võõrliigid Eestis). Tallinn, Estonian Ministry of the Environment. 72 pp. (In Estonian).

Keskkonnaminister. 2006. The list of alien tree species permitted to use in reforestation. (Metsa uuendamisel kasutada lubatud võõrpuuliikide loetelu). - RTL 2006, 87, 1597. (In Estonian).

Kull, K. 2009. Foreign and native in a park. (Võõras ja oma pargis). - Külvik M., Maiste J. (eds.). Park is Paradise in Art and Nature. (Park on paradiis looduses ja kunstis). Tartu, Estonian University of Life Sciences, 342-351. (In Estonian).

Maiste, J. 1996. Manorial Architecture in Estonia. (Eestimaa mõisad). Tallinn, Kunst. 454 pp.

Mooney, H.A., Hobbs, R.J. 2000. Invasive Species in a Changing World. Washington DC, Island Press. 384 pp.

Mölter, M. 2011. Risk assessment of non-native tree species permitted in forestry. - Master's thesis. Tartu, Estonian University of Life Sciences. 68 pp

Nurme, S., Kotval, Z., Nutt, N., Hiob, M., Salmistu, S. 2014. Baroque manorial cores and the landscape. - Journal of Cultural Heritage Management and Sustainable Development, 4(2), 166-183.

Nutt N. 2008. The design of historical parks at their height. (Ajalooliste parkide kujundus nende hiilgeajal). - Nutt, N., Maiste, J., Nurme, S., Karro, K., Sinijärv, U. (eds.). Restoration of Parks. (Parkide restaureerimine). Tallinn, Sikk ja Sakk, 75-93. (In Estonian).

Nutt, N. 2013. Dendrological authenticity of Estonian manor parks. (Eesti mõisaparkide dendroloogiline autentsus). - Acta Architecturae Naturalis, 3, 93-103. (In Estonian with English summary).

Nutt, N., Nurme, S., Hiob, M., Salmistu, S, Kotval, Z. 2013. Restoring manor parks: exploring and specifying original design and character through the study of dendrologous plants in Estonian historical manor parks. - Baltic Forestry, 19(2), 280-288.

Palm, P. 2009. Wooden plants in Estonian parks protected by the Nature Conservation Act from 19th to 20th centuries. - Master's thesis. Tartu, Estonian University of Life Sciences. 85 pp.
Pistohlkors, O.F. 1797. Botanical list of woody species native to Livonia with their various names. (Botanisches Namensverzeichniss der in Liefland einheimischen Holzarten, mit ihren verschiedenen Benennungen). - Neue Nordische Miscellaneen, 17, 172-182. (In German).

Purik, T. 2011. The risk assessment of plant species endangering natural balance. - Bachelor's thesis. Tartu, Estonian University of Life Sciences. 52 pp. (In Estonian with English summary).

Purik, T. 2013. Risk assessment of alien woody plant species recommended for restoration of parks. - Master's thesis. Tartu, Estonian University of Life Sciences. 67 pp. (In Estonian with English summary).

Purik, T., Ööpik, M. 2013. Risk assessment of alien woody plant species recommended for restoration of parks. - Acta Architecturae Naturalis, 3, 105-1256. (In Estonian with English summary).

Pyšek, P., Richardson, D.M., Pergl, J., Jarošik, V., Sixtova, Z., Weber, E. 2008. Geographical and taxonomic biases in invasion ecology. Trends in Ecology and Evolution, 23, 237-244. https:/ / doi.org/10.1016/j.tree.2008.02.002.

Raska, M. 2010. The classification of alien flora in Estonia based on their risk level. - Master's thesis. Tartu, Estonian University of Life Sciences. 53 pp. (In Estonian with English summary).

Raukas, A. 1995. Estonian Nature. (Eesti loodus). Tallinn, Valgus. 606 pp. (In Estonian).

Rosenberg, T. 1994. Estonian Manors. (Eesti mõisad). Tallinn, Olion. 304 pp. (In Estonian).

Sander, H., Elliku, J., Roht, U. 2008. The introduction and bewilderment of the most common alien deciduous trees and shrubs in Estonian parks and collections. (Eesti parkide ja kollektsioonide levinumate võorlehtpuude ja -põõsaste introduktsioonist ja metsistumisest). - Magnus, R. (ed.). Estonian Naturalists' Society Yearbook Vol. 85. Tartu, Estonian Naturalists' Society, 78-102.

Sander, H., Meikar, T. 2004. Exotic conifers in Estonian Forest Plantations. - Metsanduslikud Uurimused / Forestry Studies, 40, 41-64. (In Estonian with English summary).

Sinijärv, U. 2013. Art and nature in parks combining design objectives and biodiversity conservation objectives in park restoration and maintenance on the basis of case studies of protected parks in Saare county, Estonia. - Acta Architecturae Naturalis, 3, 45-70. (In Estonian with English summary). 
Uustal, M. 2003. Plant use in Estonian manor gardens. - Master's thesis. Tartu, Estonian Agricultural University. 113 pp. (In Estonian with English summary).

Weber, E., Gut, D. 2004. Assessing the risk of potentially invasive plant species in central Europe. - Journal for Nature Conservation, 12, 171-179. https://doi.org/10.1016/j. jnc.2004.04.002.
Ööpik, M., Bunce, R.G.H., Tischler, M. 2013. Horticultural markets promote alien species invasions: an Estonian case study of herbaceous perennials. - NeoBiota, 17, 19-37.

Ööpik, M., Kukk, T., Kull, K., Kull, T. 2008. The importance of human mediation in species establishment: analysis of the alien flora of Estonia. - Boreal Environment Research, 13, $53-67$.

Received October 10, 2019, revised January 03, 2020, accepted April 28, 2020 